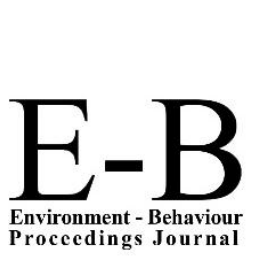

Proceedings Journal

\author{
ASLI QoL 2017 \\ AQoL2017Kuching \\ http://www.amerabra.org; $h$ ttps://fspu.uitm.edu.my/cebs \\ $3^{\text {rd }}$ ABRA International Conference on Quality of Life \\ "Quality of Life 3" \\ Riverside Majestic Hotel, Kuching, Malaysia, 14-16 Oct 2017
}

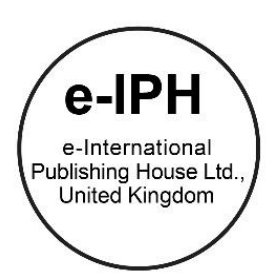

\title{
Incubator of Indigenous Baseball Dream: A case study of Fantasy Association in luye, Taiwan
}

\author{
ChunChieh, Lin ${ }^{1}$
}

1Stanley Wang D-School, National Taiwan University, No. 1, Sec. 4, Roosevelt Road, Taipei 10617, Taiwan(R.O.C)

chunchiehlin@ntu.edu.tw

Tel:+886233661883

\begin{abstract}
The objective of this essay is to examine baseball incubator is facilitated by governance failure of regional policies as opposed to initiating an alternative way of living for indigenous in Eastern Taiwan. With the perspective of regional planning, the discussion focuses on how space planning affects baseball industrial development from regional to local scale. Furthermore, the cultural meaning of baseball supplements the reason that baseball turns into the answer to this declined area. Finally, the case study of the Fantasy Association would provide a possible solution to the Eastern Taiwan, the home of indigenous baseball, in this epoch of deadlock.
\end{abstract}

Keywords: baseball; Taiwanese indigenous; uneven development; regional policy

eISSN: 2398-4287@ 2017. The Authors. Published for AMER ABRA by e-International Publishing House, Ltd., UK. This is an open access article under the CC BYNCND license (http://creativecommons.org/licenses/by-nc-nd/4.0/). Peer-review under responsibility of AMER (Association of Malaysian Environment-Behaviour Researchers), ABRA (Association of Behavioural Researchers on Asians) and cE-Bs (Centre for Environment-Behaviour Studies), Faculty of Architecture, Planning \& Surveying, Universiti Teknologi MARA, Malaysia.

https://doi.org/10.21834/e-bpj.v2i6.998

\subsection{Introduction}

Baseball, Taiwanese pastime, is the most popular sport in Taiwan of no doubt. It is also the only established professional league, Chinese Professional Baseball League, which has average drawn 950,000 attendances per year since 1990. With the understanding of the history of Taiwanese baseball, this unusual phenomenon derives from the cultural and political context of the development of national policy. Due to the tangible political crisis from international to national scale since 1970, baseball has been utilized as a target to shift the focus of national citizens by the Taiwanese government. The Taiwanese pastime becomes a camouflage of baseball to cover these complicated circumstances and narrow down the focus in the final scores of the ballgame. Disregard of well-organized development strategies to Taiwanese baseball system, the government emphasized building an all-star team to conquer all kinds of International Baseball Tournament. The indigenous baseball players are the most contributors behind Taiwanese baseball legacy.

Since the indigenous is the mainstream of Taiwanese baseball from the Japanese-Occupied period, the Eastern Taiwan, which includes Taitung County and Hualien County, has trained numerous talented ballplayers. At Sep 2017, there are total 235 native players registered in four professional baseball clubs in the league, the population of indigenous ballplayers are $34.5 \%$ of total players, which means 81 of 235 are Aboriginal ballplayers; moreover, $75 \%$ of indigenous ballplayers are from Eastern Taiwan. Surprisingly, the indigenous population is only about $2.3 \%$ of total Taiwan population; it is about 556,611 of $23,554,803$ are aboriginals. Furthermore, the Eastern Taiwan only has $30.98 \%$ of all indigenous population; It addresses Taiwanese aboriginals are very talented in baseball superficially. This peculiar state makes the Eastern Taiwan become "home of indigenous baseball."

Sports would be only accessible in an area where has the wealthy and resourceful lifestyle, for instance, the metropolis. However, the National Regional Planning (2017) indicated that Taitung and Hualien County had suffered severe declined, lack of potential of industrial development than another region. More importantly, the plan assigns the Eastern Taiwan as an important agricultural

eISSN: 2398-4287@ 2017. The Authors. Published for AMER ABRA by e-International Publishing House, Ltd., UK. This is an open access article under the CC BYNCND license (http://creativecommons.org/licenses/by-nc-nd/4.0/). Peer-review under responsibility of AMER (Association of Malaysian Environment-Behaviour Researchers), ABRA (Association of Behavioural Researchers on Asians) and cE-Bs (Centre for Environment-Behaviour Studies), Faculty of Architecture, Planning \& Surveying, Universiti Teknologi MARA, Malaysia.

https://doi.org/10.21834/e-bpj.v2i6.998 
development area. This abnormal phenomenon reveals a contradiction between the baseball dream and regional policy. In short, the absence of regional space planning perspective is the origin of failure governance of baseball and causes stagnation both Taiwanese baseball and regional development. In fact, this tactic overlooks a big, balanced picture of Taiwanese baseball, and neglect ballplayers' right in this system, and the government's policy direction brings on negative impacts of baseball industry governance, the uneven regional development and the unbalanced employment market in the series discussion of Taiwanese baseball.

This essay critically examines this abnormal circumstance that can relate to the historical context of baseball and urban planning development. With the perspective of regional planning, discussion of this paper focuses on how space planning affects baseball industrial development from regional to local scale. In spite of the examination of the relationship between baseball and urban planning, the cultural meaning of baseball supplements the reason that baseball turns into the answer in this declined area. Finally, the case study of the Fantasy Association, which has dedicated in these complicated issues since 2013, would provide a possible solution to the Eastern Taiwan, the home of indigenous baseball, in this epoch of deadlock. In the following section, I will briefly introduce the concept of nationalism of baseball, indigenous legacy, and space planning of sports, which can connect to the origin of uneven development in Eastern Taiwan, through integrating with baseball and urban planning.

\subsection{Beyond the Game: Research Methodology, Nationalism of Baseball, Indigenous Legacy, and Space Planning of Sports}

\subsection{Research Methodology}

This paper will use Secondary Qualitative Study to establish the research background, both of baseball and urban planning. Firstly, related studies of Taiwanese ingenious players will provide dispensable statistical data to support the argument of this paper on the whole map of Taiwanese ingenious legacy. More importantly, the previous argument of Taiwanese baseball studies will also address an intangible situation of ingenuous in the field of Taiwanese baseball. Secondly, studies of Taiwanese Industry would depict the historical aspect of uneven regional development, and the statistical data from Urban and Housing Development Department Council for Economic Planning and Development Executive Yuan would examine the influence of failure industrial governance in an empirical way since 1950. Finally, this paper will use case study of Fantasy Association to bring the entire ideas listed above together for responding the research question of this paper. Although this paper will only provide a framework of Taiwanese sports planning due to the word limit, the future series studies of Taiwanese Indigenous baseball will keep updated to put all the pieces together.

\subsection{Nationalism of baseball}

Anderson (1999) proposed the concept of imagined community through exploring the origin of print capitalism, he argued people would connect to each other by contact with the same medium, and these connections would accumulate as culture or civilization. In this point of view, the composition of nationalism of Taiwanese baseball must process as the same, and this mechanism would be the trigger to identify ourselves as one of the members via the same life experience, story, or even desperate circumstance. As the top 2 of baseball countries, the central idea of America and Japan is a unique substance depth mind character, and also represent the most significant value set of their culture. The American identify the baseball is a nostalgia to connect with old times; Japanese recognized the baseball as a representation of Samurai (Edward 1996; Kiku 1993). These signatures of the baseball have helped the whole society got through from political difficulties. For example, Babe Ruth, legendary player of American baseball, has been recognized a row model of the American dream by the public during the Great Depression; Japanese baseball played a symbol of revival after WWII to support the public to over come the difficulties (Szymanski \& Zimbalist 2008; Inoue 2013). The cases show how the baseball becomes their national pastime with cultural elements and turns into a faith to the country.

Likewise, the Taiwanese called the baseball as the national pastime is not just famous or popular, the rise of Taiwanese baseball attributes to the historical and political context of Taiwanese pastime because of the real crisis of Taiwanese government since 1970. Firstly, the historical aspect indicated that winning 6 times of consecutive champion titles of Little League World Series, Senior baseball World Series, and Big League World Series has incubated numerous talented amateur ballplayers at 1974, 1977, 1978, 1988, 1990, and 1991(Hsieh\&Hsieh 2003; Tseng\&Yu 2004). These ballplayers, who fully dedicated to baseball, were trained intentionally by the Taiwanese government to defend its national and international legitimacy. Secondly, the political aspect supplement that is representing the country of China of Taiwanese government was challenged by rising of People Republic of China since 1970, and the PRC states firmly "One-China" policy of implementing political insulation to Taiwanese government by diplomatic means.

Afterwards, taking titles of Baseball World Series has been regarded as a tool of political borne to enhance Taiwanese regime legitimacy. Furthermore, baseball demonstration games at 1984 summer Olympic, and the new technology of broadcasting were bringing latest sports landscape from international to Taiwan (Hsieh\&Hsieh 2003; Tseng\&Yu 2004). Both of them facilitated the birth of CPBL at 1989 and started the first baseball season at 14, Mar 1990. As a result, those talented ballplayers not only became the basis of professional baseball but also inherited the dual-meaning of Taiwanese pastime to CPBL. On the one hand, the central idea of Taiwanese baseball is to claim the legitimacy of Taiwanese regime in the political context; on the other hand, this core idea is to emphasize on the survivability of Taiwanese in the cultural context. Baseball has created the value set, which matches the route of overall development of Taiwan from an agricultural society to Industrial society.

\subsection{Indigenous Legacy}

Also, the Taiwanese pastime derived originally from the contribution of Taiwanese indigenous ballplayers; it is necessary to map out the relation between indigenous ballplayers and Taiwanese pastime for further discussion. The nationalism of baseball has always 
taken the leading position, and Taiwanese baseball has been recognized as an intermediary for promoting national harmony. In the historical perspective, Taiwanese indigenous has been regarded as natural-born athletes since the Japanese-Occupied period. The famous examples are two high school teams, NOKA and KANO, which team's members came from three major ethnicities.

The Han race, Japanese, and Taiwanese indigenous as Taiwan baseball delegation to compete with other Japanese high school teams in Hanshin Koshien stadium in National High School Baseball Summer Tournament at 1925 and 1934 in respectively. Even the Kuomintang took over Taiwan from Japan after WWII; the indigenous were still the main force of national team to compete in different International Baseball Tournament. For instance, the team members of Hong-Yeh, the most famous Taiwanese little league team which defeated the Japanese Kansai little league All-Star team at 1968, were from Taitung where named aboriginal hometown. With the success of recruiting indigenous ballplayers, Taiwanese baseball started to rely on them. At 1971 in Hualien County, Ret-Ser Engineering Agency, which was founded by Veterans Affairs Council, established the first systematic amateur baseball incubator to recruit talented indigenous baseball players from Eastern Taiwan to Taipei, capital of Taiwan (Hsieh\&Hsieh 2003; Tseng\&Yu 2004). Although the authority of this institution had declined when they dismissed the first little league baseball teams since 1988, it has turned numerous ballplayers into armature baseball super stars, and successfully enlarged the effect of baseball to attract indigenous players.

The nationalism of baseball has played the role of being in a political reality for Taiwan, and the baseball had united Taiwanese citizen to a dignity of life when the political crisis broke out at the 1970s. The nationalism establishes the image of baseball as the way to survive, and gain the fame from the world. However, overemphasizing the positive side of baseball nationalism also caused severe hidden negative impact behind the gold medals. In fact, the effect of scale penetrates both professional and armature baseball. The further professional baseball researchers focused on the subjectivity of agency on the field, and the global baseball labor movement, even more, criticizing the obsession in baseball nationalism (Tasi 2005; Ho 2006; Liou 2008; Lin 2010). On the other side, the related armature baseball studies mainly focus on the motivation of armature indigenous to play baseball (Chiu 2003; Lin 2007; Lin\&Chu 2009; Lin 2013; Lin 2015) Literally, the nationalism of baseball would play the role of attracting indigenous to be baseball players. However, Lin\&Chu (2009) did a questionnaire survey to ballplayer's motivation who are from Eastern Taiwan, the result showed $56 \%, 47.5 \%$, and $49.5 \%$ of ballplayers, from 21 elementary, 9 junior high and 4 high schools in respectively, are spontaneous to join baseball team; Only $11 \%, 5.5 \%$, and $9.5 \%$ of ballplayers are affected by TV broadcasting; the rest of $33 \%, 47 \%$, and $41 \%$ of them are encouraged by acquaintances (Table 1.).

Table 1. The factors of ballplayers to participate baseball team in Eastern Taiwan

\begin{tabular}{lllll}
\hline & Spontaneous & Broadcasting & $\begin{array}{l}\text { Encouraged by } \\
\text { acquaintances }\end{array}$ & Others \\
\hline Elementary School Students (21 teams) & $56 \%$ & $11 \%$ & $33 \%$ & $0 \%$ \\
Junior High School Students (9 teams) & $47.5 \%$ & $5.5 \%$ & $46.5 \%$ & $0.5 \%$ \\
High School Students (4 teams) & $49.5 \%$ & $9.5 \%$ & $41 \%$ & $0 \%$ \\
\hline
\end{tabular}

(Source: Lin \& Chu (2009) )

Although the result of questionnaire survey indicated that most of the ballplayers are willing to participate in the team by their willing, the result, which lack of analyzing how external factors affect ballplayers to participate, is not convincing. As Chiu (2003) argued that the integration between the nationalism of baseball and cultural, social, political network of indigenous becomes the key factor to influence aboriginal people to participate baseball team. The other notable supplement Chiu's (2003) argument, and define five external factors that affect indigenous players to play baseball: 1) discussions on their nature and constitution; 2) view about political-governance and national ideology; 3) baseball as a ladder to higher-level schools or a remedy for their learning failure; 4) the lure of economics; 5) standpoints on community culture and social construction (Lin, 2007). Whereas, I argued that Lin (2007) overlooked the effect of region declined in Eastern Taiwan. In other words, the position of this paper is to examine that the failure of space planning policies accelerates some of the people who are willing to join baseball team for chasing another chance for surviving in declined eastern Taiwan. The following part will introduce the concept of space planning of sports that play a significant role in promoting uneven development and aggregate the baseball immigration from eastern Taiwan.

\subsection{Space Planning of Sports}

Sports related studies have debated about the political economy meaning of sports space, which affects urban daily life and governance of urban planning, in a different perspective, rationalism and romanticism in character of sport in urban planning, of the entire world (Rosentraub 1997; Abe 2009; Rosentraub 2010;Park 2011; Koch 2016). One convincing point of view indicated the specialties would take advantage of the cultural aspect of sports, the collective memories, which can build up sports welfare system, to receive support from the public to boycott distribution justice of public authorities (Rosentraub 1997). Also, the other notable perspective pointed the inherent limitation of urban planning ideology, redistribution, is to provide reproduction space for enhancing the quality of life (Allmendinger 2009). The reproduction spaces would raise the cost to sustain the social welfare system, and the extra cost must requisite from the public equally. Therefore, the function of urban planning that redistributes resource for pubic fairness is deprived of sports space, which integrates with the limitation of planning and the collective memories of sports welfare system to blur boundaries between the public and private in the planning process, for increasing public good.

The major developed countries, which has professional baseball league, like America, Japan, and Korea, are confronted the same challenge of redistribution between sports and urban planning. Long (2013) argued that even America has moved toward public- 
private partnership, the average percentages of cost sharing of building sports' project between public and private sectors is still $54 \%$ and $46 \%$ in respectively. On the contrary, Japan and Korea, the strong state-led country, are difficult to establish the same cost sharing partnership. Instead, both of them either sell land development right to the private sector, such as Hanshin Koshien Stadium which was $100 \%$ built and owned by Hanshin railway company in 1924 (Ariyama 1993), or take sports development as municipal achievement, the Gocheok Sky dome which is most expensive baseball stadium in the history of Korea spent total 204 million dollars of public funding at 2015. Because the definition of publicity of sports space is not clear, the failure redistribution of urban planning is not related to planning system maturity as these cities' cases explained. Whereas, after sports mega-events, the Olympics especially, become famous affairs in a world of globalization, every city is infusing tremendous funds to be the host city to gain its global reputation (Chou 2006; Zimbalist 2016).

In these cases, the redistribution of resource is the main concern for planners; the logic of capital society, however, utilize consumption to control primary resource from metropolis to aggregate polarization between cities, and tax income of the consumption is the most iconic index of the consumption behavior for governors to develop and maintain the city. In other words, the tax is exactly the resource about which planners concern. Along with the increase in disposable income, the expansion of consumer demand impel the whole society moving forward to the consumption society, which would promote rapid commodification of products from any industrial sectors (Yu 2003); meanwhile, the change of consumption structure from durable goods to immaterial products facilitate industrial transformation. Therefore, urban planners would provide enough land capacity of specific industry sectors to support this industrial conversion in the metropolitan area. Likewise, the sports spaces are uneconomical for planners to operate and maintain the public welfare system, the tax is the key factors to support this system, and expand the demand of consumers. The prosperity of sports industry depends on the maturity of consumption society because of the industrial structure and disposable time of labors, who are potential customers for the sports industry.

From the above discussion, the policy of industrial governance can connect to space planning of sports directly. Most importantly, the regional policy-decision is not only about the polarization of space, but also play the leading role to determine the ideal location for developing sports industry. Eventually, creating a space to guide those people how to make a life. The next section will explain how Taiwanese regional planning policy made eastern Taiwan decline, how the eastern Taiwan responds to this, finally, the discussion of Fantasy Association will propose another way to revise this in Eastern Taiwan.

\subsection{Play the Game: Taiwanese Regional Planning strategy of uneven development, Eastern Taiwan's Alternative Way of Region Declined, Fantasy Association as Baseball Incubator}

\subsection{Warming up: Taiwanese Regional Planning strategy of uneven development}

The progressive industry development policy is the origin of uneven regional development from the 1950s, it leads to the re-structure of Taiwan's urban space, which results in a comprehensive change between regional industry and population redistribution. In retrospect, the devastating economy needed to recover rapidly in Taiwan after the devastating WWII, therefore, the government assigned to increase the production of agriculture, which made Land Reform be issued to increase agricultural population for maximizing the productivity by the government, to support industrial development from 1949 to 1953 . This industrial policy, form Substitution Industrialization Import (ISI) to Export Oriented Industry (EOI), also dispersed over million population, who retreated from China with Kuomintang to Taiwan at 1949, to the rural area for increasing agricultural output. Although the ratio of export production of industrial sector rose from only $8.1 \%$ to $55.1 \%$ of overall export products for 13 years from 1953 to 1966, the overall agricultural sectors, including net income and ratio of export production, was declined rapidly from 1950's to 1960's by unreasonable controlling of market price of agricultural products (Sun 1988; Tung 2012). The average price of agricultural products is $30 \%$ lower than other products in the secondary sector, and the average net profit of agricultural population is only $30 \%$ of other industries, which caused every agricultural population that carried 70\% mortgage debt to sustain this industrial system (Sun 1988, Wu 2007). Because the primary industry became less competitive than the secondary sector, the labor force population started to enter the secondary sector, which promoted the industrial transformation, instead of being in the primary sector. This change of industry structure led the overall labor force population to leave the rural area from the urban area at 1960's.

The consistent expansion of the secondary sector was located in the metropolitan area from 1960's to 1980's, forced the planners to solve the increasingly urban population growth for maintaining the quality of life (Table 2). However, the urban planning system barely lost its function due to the negative urban governance policy from 1949 to 1964. Since WWII, the exploration immigration population moved in Taiwan, and crushed the origin the green land system because the government needed to release those lands to settle these homeless, afterwards, the government was focusing on defending invasion from the People Republic of China, and developing economy to enhance legitimacy of Republic of China's regime in Taiwan, until 1964 when Japanese Urban Planning Act was revised, the government started to remedied these chaos cities (Chang 1993). Later, The Taiwan Comprehensive Development Plan, which was the first regional plan to instruct other urban planning, also decided to expand the land capacity of secondary sector at 1979 and ignored the serious declined of primary sectors (Tasi 2008). As table 2 indicated, when both industrialization and urbanization had started since 1960, the population had increased in the major regions, such as Northern Taiwan; furthermore, as the growth population, the land use zoning was increasing to support the city to contain and created more jobs for the immigration people. In short, the industrial transformation was a way to make economic growth rapidly from 1960's to 1980's; it causes two main effects to the regional development. Firstly, pushing the population moved from rural area to urban area, resulted in 
the shortage of primary sector population. Secondly, the growth of urban population provided more secondary and third sectors job opportunities in the main regions to maximize the net profit for high economic growth (Table 2).

Table 2. Land Use Zoning in Urban Planned (1979-2014)

\begin{tabular}{|c|c|c|c|c|c|c|c|c|c|c|}
\hline Year/Division & $\begin{array}{l}\text { Total } \\
\text { area } \\
\left(\mathrm{km}^{2}\right)\end{array}$ & $\begin{array}{l}\text { Planned } \\
\text { area of } \\
\text { total area }\end{array}$ & $\begin{array}{l}\text { Planned } \\
\text { area(ha) }\end{array}$ & $\begin{array}{l}\text { Planned } \\
\text { Districts }\end{array}$ & $\begin{array}{l}\text { Housing } \\
\text { Dist(ha) }\end{array}$ & $+/-$ & $\begin{array}{l}\text { Business } \\
\text { Dist(ha) }\end{array}$ & $+/-$ & $\begin{array}{l}\text { Industrial } \\
\text { Dist(ha) }\end{array}$ & $+/-$ \\
\hline \multicolumn{11}{|l|}{2014} \\
\hline Taiwan & $36,189.95$ & $13.3 \%$ & $462,812.35$ & 427 & $64,213.84$ & +911.47 & $7,894.45$ & +216.43 & $21,629.72$ & -731.84 \\
\hline Northern Taiwan & $7,353.39$ & $28.5 \%$ & $209,383.87$ & 122 & $20,870.14$ & +812.38 & $2,769.75$ & +88.50 & $8,101.19$ & -555.04 \\
\hline Central Taiwan & $10,506.88$ & $9.2 \%$ & $97,151.04$ & 130 & $17,924.20$ & +274.07 & $1,868.26$ & +52.63 & $4,600.06$ & -119.66 \\
\hline Southern Taiwan & $10,005.40$ & $13.5 \%$ & $135,388.24$ & 139 & $22,834.69$ & -136.36 & $2,956.40$ & +87.87 & $8,365.78$ & +47.72 \\
\hline Eastern Taiwan & $8,143.82$ & $2.6 \%$ & $20,889.19$ & 36 & $2,584.81$ & -39 & 300.03 & -13 & 562.69 & -105 \\
\hline \multicolumn{11}{|l|}{2004} \\
\hline Taiwan & $36,006.18$ & $12.5 \%$ & $451,520.92$ & 449 & $63,302.37$ & $+2,399.77$ & $7,678.02$ & $+1,317.09$ & $22,361.56$ & $-1,103.17$ \\
\hline Northern Taiwan & $7,353.39$ & $27.9 \%$ & $205,098.61$ & 128 & $20,057.76$ & +462.48 & $2,681.25$ & +371.69 & $8,656.23$ & -421.43 \\
\hline Central Taiwan & $10,506.88$ & $8.8 \%$ & $92,150.16$ & 127 & $17,650.13$ & +817.33 & $1,815.63$ & +244.60 & $4,719.72$ & $-1,350.25$ \\
\hline Southern Taiwan & $10,002.08$ & $13.3 \%$ & $133,149.64$ & 157 & $22,971.05$ & $+1,004.20$ & $2,868.53$ & +662.68 & $8,318.06$ & +680.69 \\
\hline Eastern Taiwan & $8,143.82$ & $2.6 \%$ & $21,122.51$ & 37 & $2,623.43$ & +116 & 312.61 & +38 & 667.55 & -12 \\
\hline \multicolumn{11}{|l|}{1994} \\
\hline Taiwan & $36,000.02$ & $12.2 \%$ & $440,150,27$ & 441 & $60,902.60$ & $+1,985.28$ & $6,360.93$ & +267.89 & $23,464.73$ & +957.66 \\
\hline Northern Taiwan & 7347.23 & $27.4 \%$ & $201,602.48$ & 123 & $19,595.28$ & $-2,371.20$ & $2,309.56$ & -157.29 & $9,077.66$ & $+1,435.02$ \\
\hline Central Taiwan & $10,506.89$ & $9.0 \%$ & $94,272.07$ & 121 & $16,832.80$ & $+2,187.09$ & $1,571.03$ & +173.85 & $6,069.97$ & $+1,716.87$ \\
\hline Southern Taiwan & $10,002.08$ & $12.7 \%$ & $127,354.30$ & 161 & $21,966.85$ & $+1,711.68$ & $2,205.85$ & +215.52 & $7,637.37$ & -202.93 \\
\hline Eastern Taiwan & 8143.82 & $2.1 \%$ & $16,921.42$ & 36 & $2,507.67$ & +458 & 274.49 & +36 & 679.73 & 9 \\
\hline \multicolumn{11}{|l|}{1984} \\
\hline Taiwan & $36,000,08$ & $11.4 \%$ & $409,061.06$ & 387 & $58,917.32$ & $+6,669.32$ & $6,093.04$ & +175.04 & $22,507.07$ & $+3,548.07$ \\
\hline Northern Taiwan & $7,347.28$ & $26.2 \%$ & $192,278.17$ & 107 & $21,966.48$ & $+2,355.48$ & $2,466.85$ & +213.85 & $7,642.64$ & $+1,108.64$ \\
\hline Central Taiwan & $10,506.89$ & $8.5 \%$ & $89,261.14$ & 115 & $14,645.71$ & $+2,279.71$ & $1,397.18$ & +156.18 & $4,353.10$ & +154.10 \\
\hline Southern Taiwan & $10,002.09$ & $11.5 \%$ & $115,361.02$ & 132 & $20,255.17$ & $+1,718.17$ & $1,990.33$ & -263.67 & $7,840.30$ & +146.30 \\
\hline Eastern Taiwan & $8,143.82$ & $1.5 \%$ & $12,160.73$ & 33 & 2049.96 & +316 & 238.68 & +69 & 671.03 & +139 \\
\hline \multicolumn{11}{|l|}{$1979^{*}$} \\
\hline Taiwan & $35,989.76$ & $8.0 \%$ & 289,066 & 303 & 52,248 & - & 5,918 & - & 18,959 & - \\
\hline Northern Taiwan & $7,347.27$ & $13.7 \%$ & 100,780 & 82 & 19,611 & - & 2,253 & - & 6,534 & - \\
\hline Central Taiwan & $10,506.89$ & $7.1 \%$ & 75,048 & 91 & 12,366 & - & 1,241 & - & 4,199 & - \\
\hline Southern Taiwan & $9,991.78$ & $10.4 \%$ & 103,747 & 106 & 18,537 & - & 2,254 & - & 7,694 & - \\
\hline Eastern Taiwan & $8,143.82$ & $1.2 \%$ & 9,491 & 24 & 1,734 & - & 170 & - & 532 & - \\
\hline
\end{tabular}

* 1979 was the first year to calculate Land Use Zoning.

(Source: Urban and Housing Development Department Council for Economic Planning and Development Executive Yuan, R.O.C.)

Table 3. Industrial distribution of employed persons (1979-2014)

\begin{tabular}{|c|c|c|c|c|c|c|c|c|}
\hline Year/Division & $\begin{array}{l}\text { Overall Population } \\
\text { (persons) }\end{array}$ & $\begin{array}{l}\text { Population } \\
\text { in planed } \\
\text { districts as } \\
\% \text { of total } \\
\text { population }\end{array}$ & $\begin{array}{l}\text { Urban } \\
\text { Population } \\
\text { (persons) }\end{array}$ & $\begin{array}{l}\text { Employment } \\
\text { rate }\end{array}$ & $\begin{array}{l}\text { Total } \\
\text { employed } \\
\text { persons } \\
\text { (persons) }\end{array}$ & $\begin{array}{l}\text { Primary } \\
\text { Industry } \\
\text { (ratio of } \\
\text { total) }\end{array}$ & $\begin{array}{l}\text { Secondary } \\
\text { Industry (ratio } \\
\text { of total) }\end{array}$ & $\begin{array}{l}\text { Tertiary } \\
\text { Industry } \\
\text { (ratio of } \\
\text { total) }\end{array}$ \\
\hline \multicolumn{9}{|l|}{2014} \\
\hline Taiwan & $23,433,753$ & $79.8 \%$ & $18,705,957$ & $58.6 \%$ & $10,967,000$ & $5.0 \%$ & $36.2 \%$ & $58.9 \%$ \\
\hline Northern Taiwan & $10,528,933$ & $88.0 \%$ & $9,261,738$ & $53.3 \%$ & $4,935,000$ & $0.9 \%$ & $34.2 \%$ & $64.9 \%$ \\
\hline Central Taiwan & $5,798,122$ & $66.9 \%$ & $3,879,659$ & $70.7 \%$ & $2,743,000$ & $8.7 \%$ & $40.6 \%$ & $50.7 \%$ \\
\hline Southern Taiwan & $6,408,617$ & $79.0 \%$ & $5,062,237$ & $60.0 \%$ & $3,037,000$ & $7.4 \%$ & $36.4 \%$ & $56.3 \%$ \\
\hline Eastern Taiwan & 557,862 & $66.6 \%$ & 371,301 & $67.9 \%$ & 252,000 & $14.4 \%$ & $22.6 \%$ & $63 \%$ \\
\hline \multicolumn{9}{|l|}{2004} \\
\hline Taiwan & $22,615,307$ & $78.1 \%$ & $17,673,030$ & $55.4 \%$ & $9,786,000$ & $6.6 \%$ & $35.2 \%$ & $58.2 \%$ \\
\hline Northern Taiwan & $9,892,419$ & $87.6 \%$ & $8,668,362$ & $49.3 \%$ & $4,276,000$ & $1.4 \%$ & $34.7 \%$ & $63.9 \%$ \\
\hline Central Taiwan & $5,700,922$ & $65.0 \%$ & $3,705,015$ & $65.8 \%$ & $2,439,000$ & $10.3 \%$ & $38.6 \%$ & $51.1 \%$ \\
\hline Southern Taiwan & $6,432,444$ & $76.4 \%$ & $4,913,638$ & $57.4 \%$ & $2,821,000$ & $10.2 \%$ & $34.1 \%$ & $55.7 \%$ \\
\hline Eastern Taiwan & 589,522 & $65.5 \%$ & 386,015 & $64.8 \%$ & 250,000 & $17.0 \%$ & $23.1 \%$ & $59.9 \%$ \\
\hline \multicolumn{9}{|l|}{1994} \\
\hline Taiwan & $21,125,792$ & $76.6 \%$ & $16,188,400$ & $55.2 \%$ & $8,937,000$ & $10.9 \%$ & $39.2 \%$ & $49.9 \%$ \\
\hline Northern Taiwan & $8,966,471$ & $88.3 \%$ & $7,915,000$ & $46.9 \%$ & $3,710,000$ & $3.1 \%$ & $39.8 \%$ & $57.1 \%$ \\
\hline Central Taiwan & $5,351,972$ & $62.6 \%$ & $3,350,000$ & $68.2 \%$ & $2,285,000$ & $17.6 \%$ & $40.4 \%$ & $42.0 \%$ \\
\hline Southern Taiwan & $6,194,384$ & $73.7 \%$ & $4,568,000$ & $58.4 \%$ & $2,668,000$ & $15.1 \%$ & $38.4 \%$ & $46.5 \%$ \\
\hline Eastern Taiwan & 612,965 & $59.6 \%$ & 365,400 & $75.0 \%$ & 274,000 & $19.3 \%$ & $30.7 \%$ & $50.0 \%$ \\
\hline \multicolumn{9}{|l|}{1984} \\
\hline Taiwan & $19,012,512$ & $72.5 \%$ & $13,774,600$ & $64.1 \%$ & $8,835,150$ & $25.0 \%$ & $32.7 \%$ & $42.3 \%$ \\
\hline Northern Taiwan & $7,693,757$ & $85.5 \%$ & $6,579,600$ & $55.2 \%$ & $3,635,076$ & $10.0 \%$ & $38.6 \%$ & $51.4 \%$ \\
\hline Central Taiwan & $4,871,221$ & $58.5 \%$ & $2,848,200$ & $80.0 \%$ & $2,279,487$ & $39.0 \%$ & $29.3 \%$ & $31.7 \%$ \\
\hline Southern Taiwan & $5,808,460$ & $69.1 \%$ & $4,013,000$ & $65.7 \%$ & $2,636,945$ & $31.8 \%$ & $28.8 \%$ & $39.4 \%$ \\
\hline Eastern Taiwan & 639,074 & $52.2 \%$ & 333,600 & $85.0 \%$ & 283,642 & $41.6 \%$ & $20.6 \%$ & $37.8 \%$ \\
\hline
\end{tabular}


1979

\begin{tabular}{lllllllll}
1979 & & & & & & \\
Taiwan & $17,479,314$ & $67.2 \%$ & $11,754,411$ & $44.1 \%$ & $7,703,404$ & $29.7 \%$ & $29.8 \%$ & $40.5 \%$ \\
Northern Taiwan & $6,766,307$ & $82.3 \%$ & $5,566,672$ & $43.3 \%$ & $2,929,153$ & $12.6 \%$ & $36.8 \%$ & $50.6 \%$ \\
Central Taiwan & $4,576,679$ & $50.9 \%$ & $2,332,374$ & $45.8 \%$ & $2,096,019$ & $43.7 \%$ & $25.6 \%$ & $30.7 \%$ \\
Southern Taiwan & $5,501,778$ & $64.5 \%$ & $3,549,032$ & $43.6 \%$ & $2,398,352$ & $36.3 \%$ & $26.4 \%$ & $37.3 \%$ \\
Eastern Taiwan & 634,550 & $47.8 \%$ & 306,333 & $44.1 \%$ & 279,880 & $45.6 \%$ & $18.3 \%$ & $36.1 \%$ \\
\hline
\end{tabular}

(Source: Urban and Housing Development Department Council for Economic Planning and Development Executive Yuan, R.O.C.)

Also, Table 4 and 5 , which in the following part, provides another evidence for supporting the argument of findings as mentioned earlier. The GDP indicated three major points: Firstly, the primary industry's GDP was declined by over-exploitation from ISI to EOI since 1960's because the commoditization of primary products which was generated from the agricultural population produce capital surplus, and this surplus was transforming to support the secondary industry; therefore, the secondary industry becomes prosperous and provide better profit to attract people from the original one. Secondly, the industrial transformation not only makes the immigration of labor force but also accelerate the polarization of the west corridor of Taiwan, including northern, central and southern Taiwan, in contrast, the Eastern Taiwan was isolated since 1970's. Thirdly, after 1980's, the second time of industrial transformation flared up the polarization in the main regions, Table 5 indicated the fact that the Northern Taiwan is taking the leading position due to the fastest economic growth rate. Although other regionals were also increasing the GDP, the poll of employed persons is too deep to compete with. In the next section, I will discuss how Eastern Taiwan responds to the context of uneven development, and baseball industry will also play a tricky role as the way to take the lead.

Table 4. Industrial GDP of Taiwan (1961-2016)

\begin{tabular}{lllll}
\hline Year & $\begin{array}{l}\text { Total GDP } \\
\text { (millions NTD) }\end{array}$ & $\begin{array}{l}\text { Primary } \\
\text { Industry (ratio } \\
\text { of total GDP) }\end{array}$ & $\begin{array}{l}\text { Secondary } \\
\text { Industry } \\
\text { (ratio of total } \\
\text { GDP) }\end{array}$ & $\begin{array}{l}\text { Tertiary } \\
\text { Industry (ratio } \\
\text { of total GDP) }\end{array}$ \\
\hline 2016 & $*$ & $1.82 \%$ & $35.04 \%$ & $63.15 \%$ \\
2002 & $9,685,551$ & $3.59 \%$ & $31.05 \%$ & $67.10 \%$ \\
1995 & $7,236,536$ & $3.48 \%$ & $36.37 \%$ & $60.15 \%$ \\
1985 & $3,314,214$ & $5.78 \%$ & $36.28 \%$ & $47.94 \%$ \\
1981 & $2,542,505$ & $7.30 \%$ & $45.47 \%$ & $47.23 \%$ \\
1971 & $1,066,722$ & $13.07 \%$ & $38.94 \%$ & $47.99 \%$ \\
1961 & 402,063 & $27.45 \%$ & $26.57 \%$ & $45.98 \%$ \\
\hline
\end{tabular}

(Source: Li (2003); Directorate General of Budget, Accounting and Statistics, Executive Yuan, R.O.C.)

Table 5. Divisional GDP of Taiwan (1981-2001)

\begin{tabular}{|c|c|c|c|c|c|}
\hline Year & $\begin{array}{l}\text { Total GDP (US } \\
\text { million dollars) }\end{array}$ & $\begin{array}{l}\text { Northern } \\
\text { Taiwan (US } \\
\text { million } \\
\text { dollars) }\end{array}$ & $\begin{array}{l}\text { Central } \\
\text { Taiwan (US } \\
\text { million } \\
\text { dollars) }\end{array}$ & $\begin{array}{l}\text { Southern } \\
\text { Taiwan (US } \\
\text { million dollars) }\end{array}$ & $\begin{array}{l}\text { Eastern } \\
\text { Taiwan (US } \\
\text { million dollars)/ } \\
\text { ratio of total } \\
\text { GDP }\end{array}$ \\
\hline 2001 & $\begin{array}{l}172,146.2 \\
(100.0 \%)\end{array}$ & $\begin{array}{l}103,275.6 \\
(60.0 \%)\end{array}$ & $\begin{array}{l}29,491.2 \\
(17.1 \%)\end{array}$ & $\begin{array}{l}37,647.5 \\
(21.9 \%)\end{array}$ & $\begin{array}{l}1,731.9 \\
(1.0 \%)\end{array}$ \\
\hline 1991 & $\begin{array}{l}85,460.1 \\
(100 \%)\end{array}$ & $\begin{array}{l}44,934.5 \\
(52.6 \%)\end{array}$ & $\begin{array}{l}17,153.3 \\
(20.1 \%)\end{array}$ & $\begin{array}{l}22,118.9 \\
(25.9 \%)\end{array}$ & $\begin{array}{l}1,253.4 \\
(1.5 \%)\end{array}$ \\
\hline 1981 & $\begin{array}{l}17,281.0 \\
(100.0 \%)\end{array}$ & $\begin{array}{l}7953.5 \\
(46 \%)\end{array}$ & $\begin{array}{l}4,309.7 \\
(24.9 \%) \\
\end{array}$ & $\begin{array}{l}4,756.1 \\
(27.5 \%)\end{array}$ & $\begin{array}{l}261.7 \\
(1.5 \%)\end{array}$ \\
\hline
\end{tabular}

\subsection{Play the Game: Eastern Taiwan's Alternative Way of Region Declined}

July 2017 was the first time that Hualien Couty Stadium was chosen to hold the iconic All-Star Game by CPBL, It was also the first time that CPBL All-Star Game in Eastern Taiwan though the box office was at the 5th place lowest, only nearly 5,000 attendances, in the history of Taiwanese All-Star Game since 1991. 10 of 20 of starting lineups, which was chosen by fans and expertise, are aboriginal players in both teams, and $100 \%$ of them are all from Eastern Taiwan. As addressed earlier, the Eastern Taiwan where the home of indigenous baseball players has surprisingly raised nearly $26 \%$ of professional players. Although the academic debate of reason about the indigenous play baseball has proposed the cultural, political, economic aspect of arguments, the discussion is still not conclusive (Chiu 2003; Lin 2007; Lin\&Chu 2009; Lin 2013; Lin 2015).

Here, I argue that the planning perspective would fully state the other story of Home of Indigenous ballplayers, Eastern Taiwan. From the planning perspective, the crucial reality of Eastern Taiwan, however, pointed out that planned has only increased $1.4 \%$ of total Eastern Taiwan which is also the lowest number in Taiwan, and amount of land zoning used for the secondary and tertiary industry has kept in lowest grade since the 1950 's(Table 2). This low urbanization level constrained the development potential of Eastern Taiwan because the Southern, Central and Northern region has enhanced 3.1\%, 2.1\%, and $15.2 \%$ in respectively. All of them have expanded the land capacity of secondary and tertiary industry, and base of employed persons has grown about 700,00, $1,000,000,2,200,000$ employees through the Eastern Taiwan only increased 70,000 employees. However, the limited land capacity of 
industrial space means limited jobs opportunities. Moreover, the Table 6 makes a supplementary explanation of the incomes trends indicated the limitation of lower income in Eastern Taiwan.

Also, Table 4 and 5, which in the following part, provides another evidence for supporting the argument of findings as mentioned earlier. The GDP indicated three major points: Firstly, the primary industry's GDP was declined by over-exploitation from ISI to EOI since 1960's because the commoditization of primary products which was generated from the agricultural population produce capital surplus, and this surplus was transforming to support the secondary industry; therefore, the secondary industry becomes prosperous and provide better profit to attract people from the original one. Secondly, the industrial transformation not only makes the immigration of labor force but also accelerate the polarization of the west corridor of Taiwan, including northern, central and southern Taiwan, in contrast, the Eastern Taiwan was isolated since 1970's. Thirdly, after 1980's, the second time of industrial transformation flared up the polarization in the central regions, Table 5 indicated the fact that the Northern Taiwan is taking the leading position due to the fastest economic growth rate. Although other regionals were also increasing the GDP, the poll of employed persons is too deep to compete with. In the next section, I will discuss how Eastern Taiwan responds to the context of uneven development, and baseball industry will also play a tricky role as the way to take the lead.

Table 6. Average Family Income and Expenditure by Region (1979-2014)

\begin{tabular}{|c|c|c|c|c|}
\hline Year/Division & Total Households & $\begin{array}{l}\text { Current income } \\
\text { per household } \\
\text { (NT\$) }\end{array}$ & $\begin{array}{l}\text { Expenditure } \\
\text { Per } \\
\text { household } \\
\text { Grand total } \\
(\mathrm{NT} \$)(1)\end{array}$ & $\begin{array}{l}\text { Expenditure per } \\
\text { household on } \\
\text { Education and } \\
\text { recreation (ratio } \\
\text { of (1)) }\end{array}$ \\
\hline \multicolumn{5}{|l|}{2014} \\
\hline Taiwan & $8,382,699$ & $1,213,703$ & 956,246 & $72,379(7.6 \%)$ \\
\hline Northern Taiwan & $3,915,074$ & $1,382,675$ & $1,088,015$ & $86,339(7.9 \%)$ \\
\hline Central Taiwan & 1,887916 & $1,088,756$ & 854,035 & $65,017(7.6 \%)$ \\
\hline Southern Taiwan & $2,333,334$ & $1,062,284$ & 844,544 & $58,066(6.9 \%)$ \\
\hline Eastern Taiwan & 206,317 & 873,552 & 662,466 & $37,653(5.7 \%)$ \\
\hline \multicolumn{5}{|l|}{2004} \\
\hline Taiwan & $7,083,445$ & $1,122,966$ & 876,064 & $92,913(10.6 \%)$ \\
\hline Northern Taiwan & $3,239,232$ & $1,299,062$ & 998,161 & $107,559(10.8 \%)$ \\
\hline Central Taiwan & $1,610,869$ & 981,319 & 799,220 & $84,843(10.6 \%)$ \\
\hline Southern Taiwan & $2,045,462$ & 980,692 & 752,525 & $77,091(10.2 \%)$ \\
\hline Eastern Taiwan & 187,882 & 849,720 & 654,150 & $55,479(8.5 \%)$ \\
\hline \multicolumn{5}{|l|}{1994} \\
\hline Taiwan & $5,635,936$ & 923,388 & 662,216 & $73,584(11.1 \%)$ \\
\hline Northern Taiwan & $2,517,495$ & $1,062,166$ & 769,661 & $91,214(11.9 \%)$ \\
\hline Central Taiwan & $1,298,697$ & 805,591 & 553,859 & $57,244(10.3 \%)$ \\
\hline Southern Taiwan & $1,659,663$ & 818,125 & 558,715 & $61,105(10.4 \%)$ \\
\hline Eastern Taiwan & 160,081 & 789,340 & 614,459 & $58,435(9.5 \%)$ \\
\hline \multicolumn{5}{|l|}{1984} \\
\hline Taiwan & $4,246,587$ & 365,385 & 283,471 & $22,005(7.7 \%)$ \\
\hline Northern Taiwan & $1,832,536$ & 414,956 & 324,695 & $27,124(8.4 \%)$ \\
\hline Central Taiwan & 995,716 & 330,520 & 251,773 & $17,588(7.0 \%)$ \\
\hline Southern Taiwan & $1,279,788$ & 327,517 & 253,326 & $18,455(7.3 \%)$ \\
\hline Eastern Taiwan & 138,547 & 312,526 & 246,473 & $19,074(7.7 \%)$ \\
\hline \multicolumn{5}{|l|}{1979} \\
\hline Taiwan & $3,593,061$ & 211,216 & 163,622 & - \\
\hline Northern Taiwan & $1,500,249$ & 245,724 & 190,321 & - \\
\hline Central Taiwan & 861,377 & 189,776 & 144,584 & - \\
\hline Southern Taiwan & $1,103,181$ & 185,959 & 146,284 & - \\
\hline Eastern Taiwan & 128,254 & 175,208 & 133,277 & - \\
\hline
\end{tabular}

(Source: Urban and Housing Development Department Council for Economic Planning and Development Executive Yuan, R.O.C.)

The lower income and limited jobs opportunities are the warnings that regional difference had been amplified, and the labors would be confronted with push-pull effect due to this severe declined. In addition, these vulnerable labors are in low educational level so they can only do entry-level work, the industrial transformation, however, upgraded industry from labor-intensive, Export Processing Zone since 1960, to technology-intensive, Science Park since 1980, and capital-intensive industry, heavy industry in Western Corridor of Taiwan; since 1960, the policy caused push-pull effect between rural to urban area, the indigenous labors either moved to other regions for entry-level jobs or stay home for lower payment work and limited employment opportunities(Lin 2005). Nevertheless, the baseball has brought the second chance to Eastern Taiwan.

Strange it is, In this declined area, which has the lowest payment and expenditure on education recreation, has the most welltrained, talented baseball players, which contradict with the premise of sports is having enough tax income to support (Table 11.). Therefore, it is necessary to clarify the socioeconomic background of ballplayers to figure the connection between lower income and being baseball players as Table 7,8, and 9 showed. In short, the limited resource is the primary concern in this region, and baseball is another contradicted factor to examine this unusual phenomenon. 
The structure of the population of junior high baseball athletes in Taitung County reveals two features of the parent, which would reduce the rate of their children to join baseball team: firstly, the higher the academic qualification; secondly, the higher the professional status (Liou 2010)(Table 7\&8). As Lin \& Chu's (2009) findings indicated that average financial statement of Aboriginal ballplayer families was assessed as poor or worse (Table 9). Moreover, Lin (2015) also found 90\% of High school aboriginal ballplayers' parents are middle and lower classes workers with a small and unstable payment system. It reveals the connection between lower academic qualification and professional status family is contrary to expectations of typical sports development; further more, these parents are looking forward returns from baseball as Lin (2013) addressed that being a professional baseball ballplayer make big money to reverse the poverty is the dream of ballplayers who come from vulnerable families. Most importantly, this phenomenon has penetrated all level of schools in Taiwan due to the baseball development policies and caused human capital of polarization toward to resource-rich areas.

Table 7. Educational Background of Ballplayer's Parent

\begin{tabular}{|c|c|c|c|c|c|c|c|}
\hline & Uneducated & $\begin{array}{l}\text { Elementary } \\
\text { School }\end{array}$ & $\begin{array}{l}\text { Junior High } \\
\text { School }\end{array}$ & High School & College & University & $\begin{array}{l}\text { Graduated } \\
\text { school }\end{array}$ \\
\hline Father & $1(1.3 \%)$ & $11(13.9 \%)$ & $23(29.1 \%)$ & $25(31.6 \%)$ & & $1(1.3 \%)$ & $1(1.3 \%)$ \\
\hline Mother & $2(2.5 \%)$ & $14(17.7 \%)$ & $24(30.4 \%)$ & $22(27.8 \%)$ & $1(1.3 \%)$ & & \\
\hline
\end{tabular}

Table 8. Vocational Background of Ballplayer's Parent (Only Father)

\begin{tabular}{|c|c|c|c|c|c|c|}
\hline & Unemployed & Primary worker & Labor Worker & Salesman & White Collar & $\begin{array}{l}\text { Upper-White } \\
\text { Collar }\end{array}$ \\
\hline Father & $8(11.8 \%)$ & $13(19.1 \%)$ & $43(63.2 \%)$ & $4(5.9 \%)$ & $0(0 \%)$ & $0(0 \%)$ \\
\hline
\end{tabular}

Table 9.Ratio of Assessment of ballplayers' Family Financial Statement by Coach

\begin{tabular}{lllll}
\hline & Very Poor & Poor & Well-off & Wealthy \\
\hline Aboriginal Family & $23.5 \%$ & $52.9 \%$ & $23 \%$ & $0 \%$ \\
Non-Aboriginal Family & $0 \%$ & $18.8 \%$ & $75 \%$ & $6.3 \%$ \\
\hline & *Sample: 33 questionnaires & & \\
& (Source: Lin \& Chu (2009)) & &
\end{tabular}

After WWII, both local baseball celebrities who inherited the Japanese baseball legend and local politicians fully supported the development of baseball, but the limited budget did not sustain teams; after the frenzy of HongYeh hit Taiwan at 1968 which ignite Taiwanese baseball, however, these post-HongYeh team boom started to head-hunt talented from Eastern Taiwan; furthermore, the government assigned three schools, Meiho High School, Huashan High School, and JungGone System to lead the baseball development, which caused great depression of Taiwanese baseball that over 200 teams dismissed due to serious unbalance redistribution from 1969 to 1980; after 1990's, the established student league protected the rest of the survival teams although the severe budget limitation has entangled all the baseball teams in Eastern Taiwan (Chang 2007).

In the even regional development perspective, the government that assigned and rewarded the schools for controlling the baseball development is inappropriate. It not only encourages the frenzy of head-hunting for players but also instigates schools to against each other for winning a game, winning government funding. In other words, Chang (2007) argued that the history of baseball development could be divided into three phases: funny ball; play ball, winning game, which is the critique of setting high threshold of playing baseball, It aggravates the situation of ballplayers who are headhunted to resource-rich areas for chasing professional baseball dream. At $2017,72 \%$ of junior high school players, who are graduated, was recruited to join high school baseball teams by other regions from 2015 to 2016, only 28\% of them stay in Taitung County; on the contrary, only 35\% of junior high players flowed out from Hualien County (Taitung County 2017; Haulien County 2017)(Tab 10). In short, the policy of "baseball designated schools" is the culprit of malignant baseball competition, and the consistent head-hunts have cleaned out the human capital of baseball in the home of indigenous and turned Eastern Taiwan into a farm that serves for teams who can be the Uncle Sam.

Table 10. Census of Graduated Junior High ballplayers form 2013 to 2016 by County

\begin{tabular}{lllll}
\hline & Pulation of & Ratio of & Pulation of & Ratio of \\
Graduated & Graduated & Graduated & Graduated \\
Junior High & Junior High & Junior High & Junior High \\
& ballplayers in & ballplayers & ballplayers & ballplayers \\
& $2013-2014$ & Migration & In 2015-2016 & Flow out \\
\hline Taitung Couty & 55 & $63 \%$ & 50 & $72 \%$ \\
Hualien County & 69 & $29 \%$ & 66 & $35 \%$ \\
\hline \multicolumn{4}{c}{ (Source: Taitung County 2017; Haulien County 2017 ) }
\end{tabular}


Sum up, firstly, the industrial transformation, which from labor-intensive to technology-intensive and capital-intensive, of the restructure of Taiwanese industrial space exploited the GDP of local primary industry, and comprehensively weaken the completeness of Eastern Taiwan, especially the entry-level labor force. Secondly, the overall declined made the baseball becomes an alternative way to increase the competitiveness of the present labor and heirs for reversing forum the poverty. As the statistical data pointed the choices of being a ballplayer is related to their socioeconomic background, especially from vulnerable family; meanwhile, the history of baseball development in this region mentioned about the various head-hunts, makes the push-pull effect on indigenous, from other regions. The resource of regions decides the final destination to the talented players, the more spending, the higher champion, and higher subsidy from the government (Tab11.).

In this discussion, no matter how spontaneous, broadcasting, and encouraged acquaintances effects their willing as Table 1 showed, or biological, cultural, political, economic aspect of baseball taught to the children. The related financial statement would be the priority to those ballplayers' family, especially the vulnerable ones. The index of economic factors would help to understand the reason of the Aboriginal choose to dream to be professional baseball players, whose career is about 4 to 5 years in average. In the next section, the case study of Fantasy Association will use another approach against this system and give a prototype to solve the deadlock of Eastern Taiwan.

Table 11. Final Statements by region (1994-2014)

\begin{tabular}{llll}
\hline Year/Division & Revenue Grand Total (NT \&millions) & Expenditure Grand Total (NT \&millions) & $\begin{array}{l}\text { Expenditure of Education } \\
\text { I (NT\$)(ratio of Expenditure Grand } \\
\text { Total) }\end{array}$ \\
\hline 2014 & & & $315,840(32.1 \%)$ \\
\hline Taiwan & & 985,103 & $148,592(32.2 \%)$ \\
Northern Taiwan & 966,331 & 461,173 & $70,018(31.7 \%)$ \\
Central Taiwan & 463,136 & 220,853 & $88,150(32.4 \%)$ \\
Southern Taiwan & 212,079 & 271,773 & $9,081(29 \%)$ \\
Eastern Taiwan & 260,391 & 31,304 & $247,715(34.4 \%)$ \\
\hline 2004 & 30,725 & & $114,185(35.4 \%)$ \\
\hline Taiwan & & 720,441 & $57,681(37.8 \%)$ \\
Northern Taiwan & 696,831 & 322,972 & $68,537(31.2 \%)$ \\
Central Taiwan & 322,131 & 152,584 & $7,312(28.8 \%)$ \\
Southern Taiwan & 140,131 & 219,529 & $166,845(34.1 \%)$ \\
Eastern Taiwan & 211,111 & 25,356 & $73,454(31.6 \%)$ \\
\hline 1994 & 23,458 & & $37,794(39.6 \%)$ \\
\hline Taiwan & & 489,096 & $49,632(34 \%)$ \\
Northern Taiwan & 494,498 & 232,627 & $5,963(37 \%)$ \\
Central Taiwan & 233,944 & 95,386 & \\
Southern Taiwan & 94,640 & 145,841 & \\
Eastern Taiwan & 149,606 & 16,100 & \\
\hline
\end{tabular}

(Source: Urban and Housing Development Department Council for Economic Planning and Development Executive Yuan, R.O.C.)

\subsection{Reversed the Game: Fantasy Association as Baseball Incubator}

Fantasy Association established a local baseball team and recruited children, 7-15 years old Now, the FA has recruited 26 members, 13 members are junior high school students, and the rest of them are elementary school students; only 3 of them are not aboriginal, and over $90 \%$ of the members are from vulnerable family. In the view of outflow of labors and ballplayers, the Fantasy Association (FA), which was established at 2015, expects to revise the declined circumstance by integrating baseball team, conduct education, and environmentally friendly agriculture into a platform, this idea responds Internal differences of Eastern Taiwan promptly. Because FA does not only care about winning ballgames, it is how to win their destiny instead.

Since the policy of "baseball assigned schools" implemented into Taiwanese student baseball system, teams have raised the budget to build up winning team by providing high standard baseball incubator, which includes training equipment, baseball field, dormitory, and the most importantly waive any possible expenditure of players. "Maintain an incubator would cost 3 to 4 million NTD per year, and It is just conservative estimate"(BA01). In general, an incubator would corporate with local schools, elementary and junior high schools mainly, to operate the team together because shortage of budget is a typical situation, schools cannot afford this tremendous amount expense except the schools, which have had its legacy, would have sponsors, alumni, celebrity, and politician, to support the team. The incubator, on the contrary, has its original social network for crowd funding. The statistical report of the ministry of education also classified the problem of the limited budget at the first place to any other sports assigned schools.

Fund, that is, is an indispensable element to both school and incubator in this region of resource dessert. Moreover, the support of education is also the other problem due to the outflow of population, which would reduce the enrollment rate (Table 12.). The school would also need the reputation of baseball to avoid budget cut or stop enrollment for sustaining the operation of a school.

Table 12. Population of $0-14$ and $15-64$ year-old by County

\begin{tabular}{llll}
\hline Year/Division & $0-14$ Year-Old Population & $15-64$ Year-Old Population & Social Increase Rate \\
\hline 2016 & & & \\
\hline Taitung Couty & 27,326 & 160,416 & $-2.81 \%$
\end{tabular}


Lin, C.C., / 3rd AQoL2017Kuching, 14-16 Oct 2017/ E-BPJ, 2(6), Nov 2017 (p.11-23)

\begin{tabular}{lccc} 
Hualien County & 41,252 & 241,010 & $-0.91 \%$ \\
\hline 2015 & & & $-5.38 \%$ \\
\hline Taitung Couty & 28,236 & 162,132 & $-2.60 \%$ \\
Hualien County & 42,148 & 243,096 & $1.83 \%$ \\
\hline 2014 & & $0.53 \%$ \\
\hline Taitung Couty & 29,724 & 163,269 & \\
Hualien County & 43,867 & 244,309 & $-3.24 \%$ \\
\hline 2013 & & $-2.17 \%$ \\
\hline Taitung Couty & 30,814 & 163,181 & \\
Hualien County & 45,072 & 244,708 & $-6.47 \%$ \\
\hline 2012 & & & $-3.76 \%$ \\
\hline Taitung Couty & 32,010 & 163,772 & \\
Hualien County & 46,389 & 245,436 & \\
\hline
\end{tabular}

(Source: The Directorate General of Budget, Accounting and Statistics (DGBAS) of Executive Yuan, R.O.C.)

In recent years, the Slugger Program, which had issued 1.163 billion NT\$ for student baseball teams from 2014 to 2017 (Tab 13.), and other baseball promotion program promote schools to establish baseball teams to expand the participation of community baseball, and the government use school as a unit. Under these circumstances, either school and incubator corporates as an ally to play the game or do nothing but wait. That is the reason that incubator is established by baseball enthusiast to sustain the system. "The founder is a crazy baseball fan, all of his life just wants to build up a baseball team, and he made his dream come true. (BS01). Usually, the incubator would fully corporate with school. However, this corporation has its tension between the incubator and school, because "Sometimes, the principal does not want a baseball team at all, that is not his/her type."(BS01) Moreover, the schoolteachers and parents have bios to the members of the team, Coach especially "(BS01) Obviously, this temporary partnership is like a tickling bump, once explode, the consequences will be irreversible. Fantasy Association had moved 7 schools from the Yuli, north of Hualien County to Luye, Taitung County in a year due to series conflicts of teaching methodology, moral issues, and ideology of baseball. "Be frankly, the parents even blackmailed the principal to file a case to sue the principle is malfeasance to fire the Coach who is not the ideal person to coach the team. And you know what, it is because he has scandals twenty years ago (BS01)."

Table 13. Subsidy Standard of Baseball Team's Level in Slugger Program Per Year

\begin{tabular}{llllll}
\hline Level & Number of Teams & $\begin{array}{l}\text { HardBall } \\
(\mathrm{NT \$})\end{array}$ & $\begin{array}{l}\text { KittenBall } \\
(\mathrm{NT \$})\end{array}$ & $\begin{array}{l}\text { Wooden-Bat } \\
(\mathrm{NT \$})\end{array}$ & $\begin{array}{l}\text { Aluminum- } \\
\text { Bat (NT\$) }\end{array}$ \\
\hline $\begin{array}{l}\text { Elementary } \\
\begin{array}{l}\text { School Teams } \\
\text { Junior High }\end{array}\end{array}$ & 426 & 150,000 & 50,000 & - & - \\
$\begin{array}{l}\text { School Teams } \\
\begin{array}{l}\text { High School } \\
\text { Teams }\end{array}\end{array}$ & 144 & 250,000 & 50,000 & - & - \\
\hline
\end{tabular}

(Source: Slugger Program (2014))

In spite of the managing problems, the headhunter, outsiders, would contact the parent for providing an offer to those likely children to play for the first-tier team instead of the second-tier one to catch their baseball dream. Once they made the deal, the parent would make the children tell an excuse to quit the original team. "Kids are not caring about whom they will play for, but the parent does. They would complain about the environment and management is not good enough for his child, or bullied by other kids. But we know that is not true."(BS01) The children were always the first one to point out these hypocritical discourses. "Why you want to leave us? You told us that you want to play baseball with us (BP01). In this case, the member, who wants to move, is the most potent player in the team. However, his parent promised the agent to transfer them to another team. The other case, a player, who was persuaded by relatives to move out for a living, left the incubator, and his confusing decision made everyone shocked. When he was caught at an Internet cafe by the FA's staff. The player rejected to back to FA, and quite the baseball eventually. "I thought he loves baseball. He just shared his dream with me; he said he wants to be a professional baseball player last month"(BS02). This deep connection between members comes from the well-organized conduct education system.

The conduct education is an alliance, which composed with local university students, volunteers, and FA's staff. The purpose of establishing this system is to increase educational resources for filling the school gap between urban and rural areas. In fact, this conduct education is the most iconic program in FA. For a long time, ballplayers are recognized themselves as meant to be "just a ballplayer," and give up school, especially in the first-tire baseball designated school. However, the FA is not on the first-tire list, this identification of performance gives these little players to think about their future career. For instance, the FA requested all of the players to write an article; the title is "If I cannot play baseball, I will be...." In this FA's paper assignment, players were felt confused about this topic although they still wrote a sports-related career, such as marathon runner, other sports athlete, as their paper's title. "Players usually do not even think about their future career actually; they are just too young to think about this life burden (BS01)"

Lin (2015), on the contrary, studied the first-tire high school players, the research indicated $60 \%$ of players choose to play baseball in Taiwan, Japan, and America or be a school coach or PE teachers; however, if they failed, $58 \%$ of them, players, are willing to join the military due to the life similarity between baseball team and military. "Officially, you can make a judgment about a kid if he has the talent to compete with other baseball elites at age 15 (BS01). "In this understanding of the limited chance to play for high 
school as a second-tier baseball team, part of the conduct education is to improve players grade for preparing future life; the staff takes the responsibility to coordinate player's daily life, university students and volunteers schedule the classes to tutor players. However, this program also has serious tensions between school and association. The school would request a subsidy from the government for extra tutoring the players during winter and summer vacation, but the teachers were not going through well with Association. Furthermore, purposes of volunteers join this program is different, for instance, some of them are want to "help these kids," they would criticize the FA that the daily-life and training schedule is too strict to these children while others may think these players are too lazy to respect this incubator. As a result, FA needs to hold a meeting to organize different opinions and mediate conflicts between volunteers and staff. Fortunately, the grade of players has improved year by year.

Besides, the association is dedicated to building up a local agricultural network, using the baseball team to promote local agriculture products. It would also be a practice field for the players to learn the skill of farming for the future career. This project has built for supporting local farmer to expand their sale distributions since 2014, the precursor of FA. Chou (2016) estimates this business model would lead the FA to be a self-sufficiency social enterprise at 2016. At first, the association wants to corporate with players' parent for helping them to improve their financial problems; however, most of the parent has no interested in this program, the decline of the agriculture has made people disappointed about the profit from the primary industry. In spite of the profit, the environmental friendly agriculture would need to invest million dollars that would be another financial burden to those parents. The FA decided to establish their own farmer's network and request a public land as the latest base to promote other local agricultural productions, for example, coffee beans, rice, jasmine jam at Luye, Taitung County. In the future view, the FA wants to connect with the local and indigenous festival to raise the reputation of both baseball team and association (Chou 2016). Although this platform, which composed of baseball, education, and agriculture, as another participatory approach to connecting local community is still in their way, the motive of FA is different from the typical incubator, which just focuses on the baseball and how to win the ballgames.

In short, the Fantasy Association realizes the complicated historical context of Eastern Taiwan; their future view is to establish a good circulation, the well-educated ballplayers with particular local skill, to keep human capital in Eastern Taiwan. Although the original idea of building up a baseball team to achieve the win-win is an ideal deal, schools would take the reputation and public funding; the founder would fulfill their life goals to help Taiwanese pastime; players will learn more than just baseball; the local family would improve their finical statement; the Eastern Taiwan would have a new-age agricultural industry to keep the population and improve its declined step by step. However, the practice of this partnership is still unstable, and it would be broken by any agency in this social network easily.

\subsection{Conclusion}

This paper has examined the baseball incubator facilitated by governance failure of regional policies, and the alternative way is just illusion to cover up the mess which was made by the government. The primary concern of the relation between sports and urban planning is the redistribution of resource is the main concern for planners; the logic of capitalist society, however, utilize consumption to control major resource from metropolis to aggregate polarization between cities, and tax income of the consumption is the most iconic index of the consumption behavior for governors to develop and maintain the city. However, the baseball development entirely contradicted with this model and turns into a malignant competition.

From the planning perspective, the industrial transformation caused a full re-structure change in Taiwan and also jeopardized Eastern Taiwan to suffer severe declined since 1950. The uneven regional development has entangled with Taiwan, with us. The perspective of regional planning provides a relatively clear view to analyze the historical, cultural, and political Taiwanese Pastime. As this paper pointed out, the failure regional governance exploited the primary industry to support the development of secondary and tertiary. However, the declined area, the Eastern Taiwan, found an alternative way because baseball played the role of savior to those people who have suffered from lower payment and limited job opportunities. Unfortunately, the inappropriate baseball designated schools policy made another push-pull effect on the baseball human capital from declined is to resource-rich areas. In the case of Eastern Taiwan, this circumstance aggregates the uneven regional development once again.

Due to the Fantasy Association is just at the beginning stage, we will not know if their strategies would reverse this nearly hopeless system. However, they helped over 26 families to know the gambling their children on baseball would not be a win-win. Moreover, they are ambitious to create a healthy circulation to substitute the vicious one in Luye. Although there are many tensions between the association, school, and parent, the strategies of Fantasy Association are worthy of experimenting. Baseball is a doubleedged sword. It creates the glory of ingenious baseball legend and also destroys the home of ingenious. However, the most difficult thing to make it right is not the baseball. In this case, the study is to open an effective communication in this complex agency network.

Finally, "Sport is the sport, Politic is politic," this famous Taiwanese saying insists there will not be a conjunction to connect with each other. To the origin of this paper is to open a new discussion between Sport and Urban Planning. In other words, the conjunction between both of them is significant to the interdisciplinary discussion. As an urban planner, this paper is a start to illustrate this complicated issue between sports and urban. However, further issues should be followed up, for instance, the difference of planning perspective between the indigenous and Han race to ponder out how different living experience would revise the inherited planning system and build up a harmony country with full respect to each other.

\section{References}


Abe, T. (2009). Hiroshima: Story of Urban and Stadium. Tokyo: Institue of PHP.

Allmendinger, P. (2009). Planning Theory. Basintoke: Palgrave.

Ariyama, T. (1997). Koshinen Baseball and Japanese. Tokyo: YoshikawaKouBunKan.

Chang, C. S. (1993). Urban Planning in Taiwan (1895 1988). Taiwan: Nieh Chiang.

Chang, T. J. (2007). A Study of Baseball Development at different levels of Schools in Taitung(1945-2005). (Master), National Taitung University, National Taitung University.

Chiang, Y. S. (2007). Industrial Planning Stretegies of Central and Sountern region. Retrieved from Chiu, W. C. (2003). Chains or Wings: Road of Indigenous Baseball Players. (Master), National Hualien University of Education, National Hualien University of Education.

Chou, C. F. (2015). Taiwanese Social Enterprise: A case study of Fantasy Association. (Master), National Central University, National Central University.

Chou, T. L. (1988). Globalization Development and Hi-Tech Industrial Policy: Review of Institutional and Spatial Perspectives. Journal of City and Planning, 25(2), 155180.

Department of National Spatial Planning and Development Naitonal Development Council, R. O. C. (Taiwan) (1979). Urban and Regional Development Statistics. Taipei: Department of National Spatial

Department of National Spatial Planning and Development Naitonal Development Council, R. O. C. (Taiwan) (1985). Urban and Regional Development Statistics. Taipei: Department of National Spatial

Department of National Spatial Planning and Development Naitonal Development Council, R. O. C. (Taiwan) (1995). Urban and Regional Development Statistics. Taipei: Department of National Spatial

Department of National Spatial Planning and Development Naitonal Development Council, R. O. C. (Taiwan) (2005). Urban and Regional Development Statistics. Taipei: Department of National Spatial

Department of National Spatial Planning and Development Naitonal Development Council, R. O. C. (Taiwan) (2015). Urban and Regional Development Statistics. Taipei: Department of National Spatial

Ho, C. H. (2006). Stay or Leave?The Migration of Taiwanese Talented Baseball Players. (Master), National Taiwan University, National Taiwan University.

Hualien County. (2017). Community Baseball Program in Hualien County 2017. Hualien: Hualien County.

Huang, S. M. (1985). The History of Urban Planning in Taiwan (1895-1945). City and Planning, 12(1), 1-20.

Huang, S. M. (1989). A Study on Transformation of Urban Structure by Reviewing Planning History of Taipei in Japanese Colonial Era (AD. 1895-1945). Journal of Building and Planning, 4, 67-83. doi:DOI : 10.6154/JBP.1989.4.005

Huang, Y. F., Kao, K. W., \& Yu, C. W. (2011). A Study on the Development History of Taitung High School Baseball: A Case Study of National Cheng Kung Commercial \& Aquaculture Senior Vocational High School. Department of P.E. \& Graduate Institute of P.E. Journal, 11, 101-116.

Inoue, H. (2013). Story of Professional Baseball Stadium in the Age of Shouwa. Tokyo: Yousensha.

Kiku, K. (1993). Historical Sociology of Modern Professional Sport : The Central Idea of Establishing Japanese Professional Baseball. Tokyo: Fumaidou. Labor Migration in Taiwan, 1980-2000. Taiwanese Journal of Sociology, 34, 147-209.

LI, I. H. (2004). A Study on the Relevance of Public Investment to the Development of Manufacturing and Producer Services. (Master), National Chengchi University, National Chengchi University.

Lin, G. N. (2010). One Hundred Years of Solitude: An Analysis of the Political Economy of the Taiwanese Baseball Development. (Master), Soochow University, Soochow University.

Lin, J. P. (2005). A Critical Review of Problems Associated with Population and

Lin, P. H., \& Chu, T. M. (2009). The Indigenous Peoples and Student Baseball in Hualien and Taitung. Sports Studies, 9, 67-108.

Lin, W. L. (2007). Behind Gold Medals: the Social Foundations and Effects of Aboriginal Baseball Dream. New Educational Ideas of Taiwanes Indigenous, 3(1), 3-28.

Lin, W. L. (2010). Indigenous Baseball Dreams: the Educational Regime, Cultural Production and Reproduction of Social Hierarchies. (Doctoral), National Taiwan University, National Taiwan University.

LIN, W. L. (2013). Contest Mobility: An Essay on the Social Mobility and Disciplinary Regime of Indigenous Baseball Players. Taiwan: A Radical Quarterly in Social Studies, 90, 43-114.

Lin, W. L. (2015). Playing Baseball, Manufacturing Differences: The Reality and Illusion of Indigenous Baseball Dreams. Physical Education Journal, 48(3), 291-308.

Liu, Y. J. (2010). The Academic Achievement of Junior High School Baseball Athletes in Taitung County. (Master), National Taitung University, National Taitung University.

Long, J. G. (2014). Public-Private Partnerships for Major League Sports Facilities. New York: Routledge.

22 
Ministry of Education. (2014). Slugger Program. Ministry of Education: Ministry of Education.

Ministry of the Interior, R. O. C. T. (2017). The Revised Naitonal Regional Plan. Taipei: Ministry of the Interior, R.O.C.(Taiwan)

Park, J. W. (2011). Elite sport development in South Korea: an analysis of policy change in the sports of athletics, archery and baseball. (Doctoral), Loughborough University.

Planning and Development for National Development Council, R.O.C. (Taiwan).

Rosentraub, M. S. (1999). Major League Losers: The Real Cost Of Sports And Who's Paying For It. New York: Basic Books.

Rosentraub, M. S. (2009). Major League Winners: Using Sports and Cultural Centers as Tools for Economic Development CRC Press.

Sun, I. C. (1988). Regional Space Policy of Taiwan. Taiwan: A Radical Quarterly in Social Studies, 1(2\&3), 33-96.

Szymanski, S., \& Zimbalist, A. (2006). National Pastime: How Americans Play Baseball and the Rest of the World Plays Soccer. Washinton: Brookings Institution Press.

Hsieh, S. Y., \& Hsieh, C.-F. (2003). Taiwan Baseball in 100 Years Taipei: Goushi.

Taitung County. (2017). Community Baseball Program in Taitung County 2017. Taitung: Taitung County.

Tsai, Y. L. (2005). Playing Ball as a Kind of Production: The LAbor Process of Taiwan's Professional Baseball Industry. Taiwan: A Radical Quarterly in Social Studies, 58, 333-352.

Tsai, Y. W. (2008). The Parsimonious City: A Critical Study of Taiwan's Post-War Urban Planning. (Master), National Tsing Hua University, National Tsing Hua University.

Tseng, W. C., \& Yu, C. W. (2004). Champion of Baseball in Taiwan. Taipei: WoShi.

Tung, C. H. (2012). The crossroads of Taiwan's agricultural development: the impact of Taiwan's agricultural policy changes on agricultural land and agriculture and rural development in the 1970s. Interlocution: University and Social Engaement, 2, 56-76.

Wu, Y. N. (2007). Where is the Underworld? the Oberservation of Taiwanese Argriculture. Taoyuan: INK.

Yukawa, M. (1932). The History of Baseball in Taiwan. Taiwan: TaiwanNichiNichiShinBou. 